Vol. 2, No. 1, Desember 2021

\title{
PELATIHAN DAN PEMBINAAN KEWIRAUSAHAAN UKM BERBASIS POTENSI LOKAL DALAM PENGEMBANGAN PARIWISATA DI KAWASAN PESISIR PANTAI CEMARA LEMBAR KABUPATEN LOMBOK BARAT
}

\author{
Masrun \\ Fakultas Ekonomi dan Bisnis Universitas Mataram \\ masrun@unram.ac.id \\ Akhmad Jufri \\ Fakultas Ekonomi dan Bisnis Universitas Mataram \\ jufri.akhmad@unram.ac.id \\ Titi Yuniarti \\ Fakultas Ekonomi dan Bisnis Universitas Mataram \\ titialamsyah61@gmail.com \\ M. Firmansyah \\ Fakultas Ekonomi dan Bisnis Universitas Mataram \\ firmansyah.feb@unram.ac.id

\section{Suprianto} \\ Fakultas Ekonomi dan Bisnis Universitas Mataram \\ pithikngguyu@gmail.com
}

Info Artikel

Diterima:

15-10-2021

Disetujui:

29-12-2021

Diterbitkan:

29-12-2021

\begin{abstract}
Abstrak
Pelatihan yang dilaksanakan ini merupakan wujud dari pelaksanaan Tridharma Perguruan Tinggi yang berupa pengabdian pada masyarakat, dengan tema "Pelatihan Dan Pembinaan Kewirausahaan UKM Berbasis Potensi Lokal Dalam Pengembangan Pariwisata Di Kawasan Pesisir Pantai Cemara Lembar Kabupaten Lombok Barat". Adapun tujuan kegiatan pelatihan dan pembinaan adalah membantu mengembangkan kemampuan pengusaha kecil mikro yang meliputi: membangun motivasi untuk berusaha, meningkatkan akses pasar dan menyiapkan masyarakat usaha kecil untuk menyesuikan diri dengan perubahan-perubahan lingkungan yang cepat dan tidak pasti.

Metode yang digunakan dalam pelatihan ini adalah melalui metode: ceramah untuk menyampaikan materi yang telah ditentukan, Tanya jawab/diskusi dan setelah pelatihan peserta akan dibina oleh tim pelaksana pengabdian.
\end{abstract}


Berdasarkan hasil pengamatan selama pelatihan berlangsung, hampir seluruh peserta yang hadir memberikan tanggapan positif (baik) pada materi pelatihan. Dengan melalui pelatihan dan pembinaan, peserta telah membawa perubahan yang meningkat, walaupun tidak signifikan dari kondisi sebelum dengan sesudahnya. Dari kondisi hasil tersebut, maka dapat direkomendasikan hal penting yaitu peserta pelatihan ini diharapkan ditindak lanjuti dengan kegiatan pendampingan, pemagangan dan studi banding ditempat pengusaha/perusahaan yang sukses.

Kata Kunci : Potensi Lokal, UKM dan Pariwisata

\section{Abstract}

This training carried out a manifestation of the implementation of the Tridharma of Higher Education in the form of community service, the theme is "Training and Development of Entrepreneurship of based on local potential in cultivation for Tourism in Coastal Areas of Cemara Lembar, West Lombok Regency." The purpose of this research is to train micro-small entrepreneurs which includes: build a motivation in business, increase market access and prepare the small business community to adapt the uncertain environment.

The method used in this training: speech to convey materials, question and answer, participants will be fostered by the community service implementation team.

According to the observation during the training, almost all participants who attend the training gave a positive (good) responses to the training materials. Through training and coaching, participants show increasing knowledge, even though insignificant from the conditions before. Based on the results concluded that the important thing is the participants in this training are expected to be followed up with assistance, apprenticeship and comparative studies at successful entrepreneurs / companies.

Keywords: Local potential, UKM and Tourism

DOI: 10.29303/abdimassangkabira.v2i1.90 


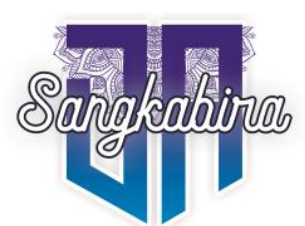

Vol. 2, No. 1, Desember 2021

\section{PENDAHALUAN \\ LatarBelakang}

Sumberdaya pesisir dan laut memberikan sumbangan yang sangat penting bagi perekonomian Indonesia, namun hingga kini pemanfaatannya belum memenuhi pemanfaatan berkelanjutan. Pemanfaatan yang dilakukan cenderung menyebabkan terjadinya kerusakan ekosistem dan kepunahan sumberdaya pesisir dan lautan. Tekanan terhadap sumberdaya pesisir dan laut semakin memburuk dalam situasi krisis ekonomi akibat terbatasnya alternative mata pencaharian masyarakat pesisir, eksploitasi menjadi jalan pintas untuk tetap mempertahankan asap dapur rumah tangga nelayan pada umumnya. Menurut Vatria (2018), kerusakan lingkungan diwilayah pantai/pesisir Indonesia samapai saat ini belum bisa ditanggulangi dengan optimal. Bahkan yang terjadi saat ini berbagai kerusakan lingkungan diwilayah pesisir semakin meluas. Penyebab kerusakan tersebut lebih didominasi oleh pencemaran sampah, abrasi pantai, kerusakan mangrove dan terumbu karang. Penyebab kerusakan itu terlihat bahwa aktivitas manusialah yang menjadi penyebab utama dengan terancamnya pemukiman dan mata pencaharian masayarakat pesisir. Oleh karena itu apabila tidak secepatnya ditanggulangi dengan optimal maka dikhawatirkan sumberdaya pesisir dan lautakan semakin terdegradasi dan aktivitas masyarakat pesisir akan semakin terancam.

Pembangunan sektor pariwisata merupakan penjabaran dan sasaran pengembang Nasional. Berbagai dasar pemikiran telah dirumuskan sebagai pedoman dalam pembangunan kepariwisataan pada masa mendatang yang penuh dengan harapan dan tantangan. Konsep pembangunan kepariwisataan berbasis masyarakat menetapkan masyarakat sebagai bagian yang terpisahkan dari produk wisata. Produk pariwisata merupakan proses rekayasa sosial (social engenering) masyarakat dan esensi pembangunan pada komunitas atau masyarakat (communiti based development). Konsep pembangunan tersebut merupakan salah satu pendekatan yang memiliki nilai strategis. Di satu pihak, pendekatan ini diyakini mampu menciptakan produk wisata yang bercirikan lokal sebagian modal dasar perencanaan dan pemasaran produk, dilain pihak, akan dapat menciptakan ketahanan dan kestabilan sosial ekonomi masyarakat. Dengan demikian pembangunan pariwisata yang bertumpu pada kekuatan masyarakat dapat berfungsisebagai asset dan kekuatan dasar kepariwisataan nasional dan daerah.

Dalam rangka mengantisipasi keadaan tersebut maka diupayaan program pengembangan masyarakat pesisir dan nelayan kecil (Marginal Fishing Community Development Pilot MFCDP) pada hakekatnya merupakan program pemberdayaan masyarakat pesisir dan nelayan kecil, dimana selama ini mereka merupakan salah satu kelompok masyarakat yang terpinggirkan. Program ini menitik beratkan pada keterlibatan 
masyarakat pesisir dan nelayan kecil dalam mengelola kawasan pesisir, peningkatan aktifitas dari proses perencanaan dan membantu memecahkan masalah-masalah pengelolaan kawasan pesisir serta mengembangkan kegiatan perekonomian dengan memberikan kesempatan penuh dalam pengembangan usaha (Bappenas, 2004).

Salah satu program untuk menanggulangi problem tersebut adalah pemberdayaan masyarakat UKM diwilayah pesisir/pantai. Program ini pada hakekatnya diarahkan untuk mengembangkan dan mematangkan berbagai potensi sumberdaya yang ada pada wilayah tersebut. Pemberdayaan UKM ditengah arus globalisasi dan tingginya persaingan membuat UKM harus mampu menghadapi tantangan global, seperti meningkatkan inovasi produk dan jasa, pengembangan SDM dan teknologi serta perluasan area pemasaran. Hal ini perlu dilakukan, mengingat UKM adalah sektor ekonomi yang mampu menyerap tenaga kerja terbesar di Indonesia (Sudaryanto, 2011). Salah satu cara pemberdayaan masyarakat UKM ini melalui jalur pelatihan dan pendampingan kewirausahaan dengan harapan dapat meningkatkan pengetahuan dan ketrampilan usahanya.

Melalui pengajaran/pelatihan kewirausahaan, pengusaha UKM mampu mewujudkan semangat perilaku dan kemampuan untuk memberikan tanggapan yang positif terhadap peluang memperoleh keuntungan untuk diri sendiri dan atau pelayanan yang lebih baik, serta menciptakan dan menyediakan produk yang lebih bermanfaat dan menerapkan cara kerja yang efisien, melalui keberanian mengambil resiko, kreativitas dan inovasi serta kemampuan manajemen. Ini sesuai dengan pendapat Pratikno (2015), tidak dipungkiri bahwa sebagai dasar berkembangnya kewirausahaan, industri kreatif dan kearifan lokal merupakan sumber pengetahuan yang dinamis berkembang, diteruskan dalam bentuk perilaku para pengusaha dan bisa menjadi inspirasi kreatif untuk pengembangan model pengajaran/pelatihan kewirausahaan. Sedangkan menurut Fitria (2019), bahwa kewirausahaan merupakan suatu sikap dan kemampuan seseorang dalam menangani usaha, menciptakan dan menerapkan cara kerja dari teknologi dan produk baru dengan cara meningkatkan efisiensi agar bisa memberikan pelayanan yang lebih baik serta memperoleh keuntungan yang lebih besar.

Kemiskinan adalah masalah struktural, maka upaya untuk mengatasi kemiskinan dikaitkan dengan perbaikan sistem dan struktur, tidak sematamata bertumpu pada aksi sesaat berupa crash program. Sebuah upaya yang dapat dikembangkan adalah melalui konsep pembinaan sikap mental wirausaha pengusaha UKM. Kucuran dana dan modal sajati tidak cukup, pembukaan kesempatan kerja juga belum tentu memperdayakan, bahkan bisa menimbulkan ketergantungan. Namun disisi lain, penanganan kemiskinan secara sporadis, tanpa desain atau skema penanggulangan terpadu yang jelas indicator pencapaiannya, juga dapat menggagalkan 


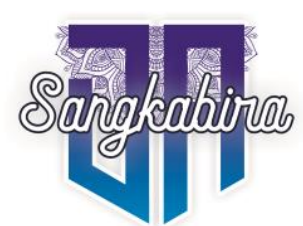

Vol. 2, No. 1, Desember 2021

upaya mengeluarkan orang dari lingkaran kemiskinan (Achmad E, dkk, 2011)

Pengembangan UKM menjadi suatuhal yang krusial mengingat UKM menjadi perwujudan konkrit dari kegiatan ekonomi rakyat yang bertumpu pada kekuatan sendiri, terdisentralisasi, beragam dan merupakan kelompok usaha yang mampu menjadi penyangga saat perekonomian dilanda krisis (Sulistyo, 2010). Ini, menunjukkan bahwa UKM mempunyai kemampuan untuk memperkuat struktur perekonomian nasional. Meskipun secara ekonomi UKM mempunyai kontribusi yang signifikan terhadap pertumbuhan ekonomi, namun dalam pengembangannya menghadapi berbagai permasalahan. Menurut Situmorang (2008) permasalahan yang dihadapi Usaha Kecil adalah (a) kurang permodalan, (b) kesulitan dalam pemasaran, (c) struktur organisasi sederhana dengan pembangian kerja yang tidak baku, (d) kualitas manajemen rendah, (e) kebanyakan tidak mempunyai laporan keuangan, (f) SDM terbatas dan kualitasnya rendah, (g) aspek legalitas lemah $(\mathrm{h})$ rendahnya kualitas teknologi.

Kondisi ini mengakibatkan lemahnya jaringan usaha, keterbatasan kemampuan penetrasi pasar dan diversifikasi pasar, skala ekonomi terlalu kecil sehingga sukar menekan biaya, margin keuntungan sangat kecil dan lebih jauh lagi Usaha Kecil tidak memiliki keunggulan kompetitif, sehingga membawa dampak pada kondisi ekonominya dengan katagori miskin. Kemiskinan merupakan masalah struktural, maka upaya untuk mengatasinya kaitkan dengan perbaikan sistem dan struktur, tidak sematamata bertumpu pada aksi sesaat berupa crash program. Sebuah upaya yang dapat dikembangkan adalah melalui konsep pembinaan sikap mental wirausaha pengusaha UKM. Kucuran dana dan modal saja tidak cukup, pembukaan kesempatan kerja juga belum tentu memperdayakan, bahkan bisa menimbulkan ketergantungan. Namun disisi lain, penanganan kemiskinan secara sporadis, tanpa desain atau skema penanggulangan terpadu yang jelas indicator pencapaiannya, juga dapat menggagalkan upaya mengeluarkan orang dari lingkaran kemiskinan (Achmad E, dkk, 2011)

Produk UKM di kawasan pesisir, sesuai dengan sifat dasarnya produk-produk perikanan sangat tergantung pada musim. Saat musim panen, hasil tangkapan dan produk nelayan sangat berlimpah dan sebaliknya pada saat paceklik produknya sangat terbatas atau bahkan tidak ada sama sekali. Selain itu, karena produk perikanan diwilayah pesisir dan laut juga tidak tahan lama, sehingga upaya peningkatan keterampilan terkait dengan teknik penanganan pasca panen harus dilakukan. Menurut (Achmad E,dkk, 2008) bahwa hasil tangkapan maupun hasil budidaya ikan/udang dipantai Cemara kecamatan Lembar kabupaten Lombok Barat cukup tinggi dengan jenis ikan yang ditangkap maupun yang dibudidayakan diantaranya ikan bandeng, udang, kepiting karang dan udang kecil (rebon). 
Hasil pelaksanaan kegiatan pasca panen ikan/udang oleh Konsursium Mitra Bahari (KMB) Regional NTB Mataram pada tahun 2007 dikawasan pantai Cemara Lembar kabupaten Lombok Barat, bahwa: (a) pembuatan aneka produk dari ikan maupun udang merupakan alternative terbaik untuk memaksimalkan pemanfaatan ikan maupun udang, diantaranya dibuat produk abon ikan, terasi udang dan bandeng presto, (b) dapat menambah keahlian para anggota Kelompok Usaha Bersama (KUB) Bina Sejahtera yang pada gilirannya dapat meningkatkan kesejahteraan hidupnya.

Propinsi Nusa Tenggara Barat (NTB) dengan jumlah penduduk 5.013 .687 jiwa (72\%) tinggal dipesisir, memiliki potensi kelautan dan perikanan yang cukup menjanjikan karena luas perairan laut $(29.259,04$ $\mathrm{km}$ ) yang lebih besar dari luas daratannya $(20.153,15 \mathrm{~km})$ dan panjang garis pantai sekitar $2.333 \mathrm{~km}$ serta 137 buah pulau-pulau kecil yang sangat potensial untuk pengembangan perikanan dan wisata bahari (BPS Propinsi NTB, 2018). Sementaraitu, daerah pesisir Kabupaten Lombok Barat menjadi salah satu lumbung kemiskinan, pasalnya jumlah warga miskin didaerah pesisir termasuk tinggi. Untuk mengentaskan warga miskin di daerah pesisir, Pemerintah Daerah Kabupaten Lombok Barat melakukan berbagai terobosan untuk memaksimalkan potensi alam yang dimiliki seperti potensi ikan, rumput laut, pariwisata pantai dan alam (BPS Kabupaten Lombok Barat, 2018)

Kawasan Pantai Cemara Lembar Kabupaten Lombok Barat merupakan kawasan pesisir yang memiliki potensi perikanan dan kelautan yang cukup besar, disamping sektor pariwisata dan potensi alam lainnya. Kawasan ini memiliki potensi perikanan tangkap, usaha produksi lainnya,pengembangan wisata bahari dan wisata tanaman mangrove (bakau). Kawasan Pantai Cemara Lembar suatu kawasan paling dekat dengan Labuhan Lembar yang merupakan urat nadi perhubungan antara Pulau Lombok dan Pulau Bali. Oleh karena itu memiliki konsekwensi yang besar baik positif maupun negative pada lingkungan fisik maupun sosial ekonomi dan berkembangnya daerah Pelabuhan Lembar.

Dari informasi yang diperoleh, pengusaha kecil selain sebagai jasa penyedia perahu, motor boat, pohon mangrove (bakau) dan juga berprofesi sebagai pedagang pengumpul, pedagang bakulan, usaha kios serta usaha produksi lainya (seperti terasi udang, kerupuk udang, dan lain lain, yang bahan bakunya dari tangkapan nelayan). Kondisi umum pengusaha kecil di kawasan pesisir Pantai Cemara Lembar dari sisi manajemen kewirausahaannya masih lemah/kurang.

\section{PermasalahanPengusaha Kecil Mikro}

Masalah umum yang dialamimasyarakat Usaha Kecil Mikro (UKM)dikawasanpesisir Pantai Cemara Lembar Kabupaten Lombok Barat yang perludicarikansolusinya, antaralain : 


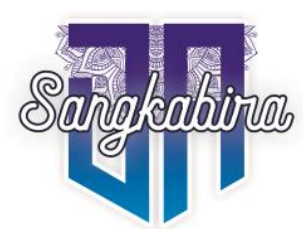

Vol. 2, No. 1, Desember 2021

1. Tidak mempunyai kemampuan manajerial

2. Tidak memiliki rencana usaha

3. Etos kerja rendah

4. Informasi dan akses terbatas

5. Tidak memiliki catatan administrasi usaha yang memadai

6. Pemasaran produk yang lemah

7. Kurang dapat mengendalikan keuangan

8. Kemampuan daya tawar dan negosiasi yang terbatas

9. Tidak memiliki wawasan bisnis

\section{KerangkaPemecahanMasalah}

Untuk memecahkan permasalahan yang dihadapi masyarakat dapat dilakukan dengan meningkatkan pengetahuan/ketrampilan melalaui kegiatan pelatihan motivasi kewirausahaan. Kegiatan ini merupakan alternative untuk merubah kondisi ekonominya dan sebagai upaya untuk meningkatkan kesejahteraan masyarakat. Dalam pelatihan tersebut, selain tutor memberikan materi motivasi kewirausahaan, juga dilakukan tanya jawab/diskusi. Pada diskusiini, masyarakat peserta pelatihan dapat menyampaikan kondisi permasalahan yang dihadapi dalam usaha yang dijalankan selama ini.

Usaha yang akan dikembangkan pada suatu kawasan pesisir Pantai Cemara Lembar Kabupaten Lombok Barat akan disesuaikan dengan potensi sumberdaya dan kebutuhan masyarakat, kepada masyarakat sasaran akan diberikan pelatihan.

Indikator capaian yang diharapkan melalui pembinaan wirausaha UKM ini dapat membawa perubahan peningkatan keterampilan pengusaha kecil secara signifikan dan terukur pada berikut ini:

\begin{tabular}{|l|l|l|l|}
\hline No & Kegiatan & KondisiSebelum & KondisiSesudah \\
\hline 1 & $\begin{array}{l}\text { Pengelolaanu } \\
\text { saha }\end{array}$ & $\begin{array}{l}\text {-Tdk memiliki rencana } \\
\text { usaha } \\
\text {-Belum terampil pencatatan } \\
\text { dan laporan keuangan } \\
\text {-Kemampuan pendekatan } \\
\text { dan negosiasi rendah }\end{array}$ & $\begin{array}{l}\text {-Memiliki rencana usaha } \\
\text {-Terampil dalam } \\
\text { pencatatan dan laporan } \\
\text { keuangan } \\
\text {-Mempunyai kemampuan } \\
\text { pendekatan dan terampil } \\
\text { dalam negosiasi }\end{array}$ \\
\hline 2 & $\begin{array}{l}\text { Penguasaan } \\
\text { pasar }\end{array}$ & $\begin{array}{l}\text {-Segmen pasar terbatas } \\
\text { - } \begin{array}{l}\text { - } \\
\text { delum ada kerjasaman pihak lain }\end{array}\end{array}$ & $\begin{array}{l}\text {-Segmen pasar luas } \\
\text {-Adanya kerjasama dengan } \\
\text { pihak lain }\end{array}$ \\
\hline 3 & $\begin{array}{l}\text { Penanganan } \\
\text { produk/ } \\
\text { produksi }\end{array}$ & $\begin{array}{l}\text { Memiliki peralatan manual } \\
\text { /sederhana } \\
\text { Penanganan produk } \\
\text { memenuhi standar }\end{array}$ & $\begin{array}{l}\text { modern } \\
\text {-Penangnan produk semi } \\
\text { memenuhi standar }\end{array}$ \\
\hline 4. & Etoskerja & -Kurang disiplin kerja & -Adanya disiplin kerja \\
\hline
\end{tabular}


Masrun, dkk: Pelatihan Dan Pembinaan Kewirausahaan UKM Berbasis Potensi.

\begin{tabular}{|c|c|c|c|}
\hline & & $\begin{array}{l}\text {-Kurang semangat kerja } \\
\text {-Kurang percaya diri dan } \\
\text { optimisme } \\
\text {-Kurng beroriantsi pd laba } \\
\text { /hasil }\end{array}$ & $\begin{array}{l}\text {-Tinggi semangat kerja } \\
\text {-Percaya diri dan optimis } \\
\text {-Beroriantasi pada laba/ } \\
\text { hasil } \\
\text {-Berinisiatif dan kreatif }\end{array}$ \\
\hline & & -Kurang in & \\
\hline
\end{tabular}

\section{TujuanKegiatan}

Tujuan kegiatan adalah membantu mengembangkan kemampuan pengusaha kecil mikro melalui pelatihan kewirausahaan yang meliputi :

1. Membangun sikap, mentalitas dan motivasi untuk berusaha

2. Meningkatkan keterampilan pengelolaan usaha

3. Meningkatkan wawasan bisnis

4. Meningkatkan penguasaan akses pasar

5. Menyiapkan pengusaha kecil mikro untuk menyesuaikan diri dengan perubahan-perubahan lingkungan yang cepat dan tidak pasti

\section{METODE KEGIATAN}

\section{Pelaksanaan Kegiatan}

Metode yang digunakan dalam pelatihan ini adalah melalui :

Ceramah untuk menyampaikan materi-materi yang telah ditentukan

1. Tanya jawab/diskusi

2. Pada akhir pelatihan, peserta dibagikan isian untuk memperoleh umpan balik tentang: (a) materi pelatihan yang diberikan oleh tim. (b) system/metode yang digunakan. (c) saran/masukan untuk tim pelaksana.

Materi yang diberikan pada pelatihan tersebut, antara lain :

1. Kewirausahaan

2. Manajemen Pengelolaan Usaha

3. Manajemen Keuangan

4. Pemasaran Produk

5. Rencana Pendirian/Pengembangan Usaha

Kami dari Tim dengan jujur untuk tidak menyembunyikan bahwa diantara para peserta yang hadir ada yang sudah memahami tentang materi sebelum dilakukan pelatihan, tetapi sebagian besar peserta yang hadir masih belum memahami materi tersebut. Setelah diadakan pelatihan, para peserta akan dimbimbing oleh Tim untuk memberikan arahan yang terkait dengan pengelolaan usahanya.

\section{Khalayak Sasaran}

Sebagai sasaran kegiatan pelatihan ini adalah pengusaha kecil mikro yang telah memenuhi criteria ditentukan yang berada diwilayah kawasan pesisir Pantai Cemara Lembar Kabupaten Lombok Barat.

Kriteria yang dimaksud adalah : 
1. Memiliki usaha yang bergerak dibidang produksi dan perdagangan.

2. Memiliki pengalaman usaha 2 (dua) tahun.

3. Mempunyai komitmen untuk ingin maju dan berkembang.

Selanjutnya dalam mengidentifikasi peserta dengan beracuan pada criteria tersebut di atas, maka ditetapkan/ditentukan peserta pelatihan sekaligus untuk dimbimbing sebanyak 20 orang

\section{HASIL DAN PEMBAHASAN Pelatihan}

Ceramah yang disampaikan oleh Tim pengabdian pada masyarakat dengan materi pelatihan, rupanya seluruh peserta yang hadir memberikan tanggapan yang baik (positif). Ini terlihat dari beberapa peserta dengan antusias dalam diskusi (Tanya jawab) dengan tutor (tim) selama pelatihan berlangsung.

\section{Bimbingan dan Evaluasi}

Selama kegiatan berlangsung tampak perhatian dan antusias peserta cukup tinggi, hal ini dapat dilihat pada saat ceramah/tatap muka dalam rangka penyampaian materi pelatihan berlangsung. Peserta pelatihan secara sungguh-sungguh memperhatikan dan mengikutinya. Demikian juga pada saat diskusi berlangsung serta juga mengajukan berbagai pertanyaan yang berkaitan dengan penyampaian materi yang masih belum jelas.

Setelah selesai pelatihan para peserta ditindak lanjuti dengan bimbingan melalui tahapan antara lain:

1. Mengidentifikasi kondisi peserta yang diidentifikasi kondisi peserta adalah tentang usaha dan permasalahan yang dihadapinya. Usaha dari peserta setelah diidentifikasi ada 4 (empat), yaitu antara lain:

a).Usaha produksi hasil laut, b).Penangkapan ikan/nelayan, c).Pengepul ikan dan d). Usaha dagang.

Sedangkan masalah yang dihadapi oleh peserta dapat teridentifikasi sebagai berikut:

a).Kesulitan pemasaran, b).Kurang bimbingan dan pembinaan dari instansi terkait, c).Hargajualrendah, d). Alat transportasi, e).Tingkat pendapatan yang tidak konsisten, f).Peralatan dan modal usaha dan g). Teknologi masih tradisional.

2. Mengevaluasi kegiatan Bimbingan

Berdasarkan hasil evaluasi terhadap 20 peserta bimbingan di kawasan pesisir Cemara Lembar, baik sebelum maupun setelah pelatihan motivasi kewirausahaan dapat diuraikan pada tabel berikut:

Tabel: Persentase rata-rata nilai motivasi kewirausahaan peserta bimbingan di Dusun Cemara Lembar 


\begin{tabular}{|l|c|c|c|}
\hline Kategori & Sebelum (\%) & Sesudah (\%) & Perubahan (\%) \\
\hline Lemah sekali & 12,31 & 13,10 & 0,79 \\
Lemah & 17,18 & 18,36 & 1,18 \\
Sedang & 18,51 & 19,06 & 0,55 \\
Kuat & 2,08 & 2,15 & 0,07 \\
Kuatsekali & 1,57 & 1,57 & 0 \\
& & & \\
\hline
\end{tabular}

Tabel di atas menunjukkan terdapat perbedaan/perubahan nilai motivasi kewirausahaan bimbingan sebelum dan sesudah pelatihan dan pembimbingan oleh Tim pengabdian pada masyarakat di dusun Cemara Lembar. Sebelum adanya pelatihan dan pembimbingan nilai motivasi kewirausahaan peserta untuk kategori sangat kuat sebesar 1,57 persen, ternyata tidak menunjukkan perubahan yaitu tetap nilai skor yang sama setelah diadakan pelatihan dan pembimbingan. Sedangkan pada nilai motivasi kewirausahaan peserta yang tergolong kategori kuat, dimana sebelum pelatihan dan pembinaan rata-ratanya sebesar 2,08 persen, setelah pelatihan dan pembinaan hampir tidak mengalami perubahan, karena hanya memberikan skor sebesar 2,15 persen.

Bila kita melihat sebelum pelatihan dan pembinaan kategori sedang, lemah dan lemah sekali masing-masing skor 18,51 persen, 17,18 persen dan 12,31 persen, ketika diberikan pelatihan dan pembimbingan menunjukkan perubahan kenaikan yang tidak terlalu signifikan. Kenaikan yang dimaksud adalah masing-masing 19,06 persen, 18,36 persen dan 13,10 persen.

Dari hasil kajian ini menggambarkan bahwa perlakukan pelatihan dan pembimbingan yang diberikan pada 20 peserta tersebut menunjukkan perubahan, namun perubahan kenaikan yang relative kecil (tidak signifikan). Namun demikian, kesimpulan pelatihan dan pembimbingan memberikan informasi yang sangat berharga untuk kegiatan lebih lanjut sehingga dapat dijadikan sebagai dasar penentuan kebijakan dimasa yang akan datang.

\section{Faktor Pendorong}

Sebagai faktor pendorong dalam kegiatan pengabdian pada masyarakat ini adalah berasal dari berbagai pihak, antara lain Lembaga Penelitian Dan Pengabdian

Kepada Masyarakat (LPPM) Universitas Mataram yang menyetujui kegiatan pelatihan tersebut. Dari Kepala Dusun Cemara Lembar secara positif memberikan dukungan untuk terselenggaranya kegiatan, seperti memotivasi peserta pelatihan dan menyediakan tempat pelatihan.

\section{Faktor Penghambat}

Secara umum dari pelaksanaan kegiatan pengabdian ini sejak perencanaan sampai dilangsungkannya kegiatan baik pelatihan maupun 
pembimbingan, tidak memperoleh hambatan berarti. Namun demikian sebagai hambatan yang mungkinakan dapat mempengaruhi tercapainya tujuan adalah adanya istilah asing dalam materi pelatihan dan adanya persepsi bahwa kondisi harga yang terus naik, sehingga sulit untuk mengimbangi biaya operasional usahanya.

\section{KESIMPULAN DAN SARAN \\ Kesimpulan}

1. Kegiatan peningkatan manajemen usaha kecil mikro melalui pelatihan kewirausahaan pada masyarakat pesisir, dapat memberikan wawasan tentang materi diberikan.

2. Melalui pelatihan dan pembimbingan, peserta telah membawa perubahan yang meningkat dari kondisi sebelum dengan sesudahnya.

\section{Saran}

1. Peranan bimbingan dari pihak yang terkait sangat dibutuhkan dalam upaya peningkatan pengelolaan usaha, pemasaran produk, manajemen keuangan dan rencana/pengembangan usaha secara berkesinambungan.

2. Bahwa kegiatan pelatihan dan pembimbingan sekarang, hanya sebagai awal dan akan berhasil dengan baik kalau dilaksanakan secara menyeluruh dan berkesinambungan.

\section{UCAPAN TERIMA KASIH}

Untuk dapat terlaksananya kegiatan pelatihan dan pembinaan/bimbingan ini, maka dari tim Pengabdian Pada Masyarakat Fakultas Ekonomi Dan Bisnis Universitas Mataram menyampaikan ucapan terima kasih kepada :

a. Lembaga PenelitianDan Pengabdian Kepada Masyarakat (LPPM) Universitas Mataram, yang memberikan dana untuk menunjang dalam pelaksanaan pelatihan dan pembinaan terhadap masyarakat khlayak sasaran (UKM)

b. Kepala Dusun Kawasan Pesisir Cemara Lembar Kabupaten Lombok Barat berperan untuk mengidentifikasi masyarakat yang akan menjadi peserta dan menyediakan fasilitas pelaksanaan pelatihan.

c. Masyarakat khalayak sasaran, berperan sebagai peserta pelatihan dan akan dimbimbing oleh tim pengabdian pada masyarakat.

Tujuan dan manfaat pengadian masyarakat melalui pelatihan dan bimbingan akan tercapai, apa bila interkoneksi ini dapat berjalan dengan baik. 


\section{DAFTAR PUSTAKA}

Achmad, E, dkk, 2008, Analisis Ekonomi Ekologis Sumberdaya Pesisir Pantai Cemara Kabupaten Lombok Barat, Proyek Pengembangan Kapasitas Riptek Masyarakat Kementrian Riset dan Teknologi, Jakarta

Achmad E, dkk, 2011, Pengentasan Kemiskinan Melalui Pembinaan Sikap Mental Wirausaha Pada Masyarakat Pesisir Desa Kebun Talu Labuhan Tereng Kecamatan Lembar, Lombok Barat

Bappenas, 2004, MembangunPerikananMenuju Abad ke 21, Jakarta

BPS Lombok Barat, 2018, Kabupaten Lombok BaratDalam Angka, GiriMenang

BPS NTB, 2018, Nusa Tenggara Barat Dalam Angka, Mataram KMB, 2007, Pelatihan Kewirausahaan Wanita Nelayan Di Pantai Cemara Lembar, Kabupaten Lombok Barat

Fitrya, 2019, Gloserium, Media Sosial, EtalaseBisnis, Jakarta

Pratikto, H, 2015, Makalah Pengukuhan Guru Besar, Pembelajaran Kewirausahaan Dan Pemberdayaan UKMK Berbasis Kearifan Lokal Untuk Penguatan Ekonomi, Universitas Negeri Malang.

Sudaryanto, 2011, The Need For ICT-Education For Manager Or Agribusinessman To Increasing For Income : Study Of Faktor Influences On Computer Adoption In East Java Farm Agribusinessman. Internasional Journal of Education And Develompment, Jedict

Sulistyo, 2010, Jurnal Ekonomi "Modernisasi" Pengembangan UKM Dengan Basis Ekonomi Kerakyatan Di kabupaten Malang, Fak. Ekonomi Universitas Kanjuruhan Malang

Sutomorang, J, 2008, Strategi Usaha Kecil Dalam Menghadapi Iklim Usaha, Infokop, Tahun XXIV

Vatria, B, 2018, "Jurnal Belian" Berbagai Kegiatan Manusia Yang Dapat Menyebabkan Terjadinya Degradasi Ekosistem Pantai Serta Dampak Yang Ditimbulkannya, Jurusan Ilmu Kelautan dan Perikanan Politeknik Negeri Pontionak 